\title{
LOCAL WISDOM ULUR-ULUR TLAGA BURET CEREMONY IN TULUNGAGUNG
}

\author{
Eka Nurwaselina Santoso $^{1 *}$; Nugraheni Eko Wardani²; Atikah Anindyarini ${ }^{3}$ \\ 1,2,3Pendidikan Bahasa dan Sastra Daerah, Fakultas Keguruan dan Ilmu Pendidikan, Universitas Sebelas Maret \\ Jl. Ir. Sutami No. 36-A, Kentingan, Surakarta 57126, Indonesia \\ ${ }^{1}$ linasantoso1996@gmail.com; ${ }^{2}$ nugraheniekowardani_99@yahoo.co.id; ${ }^{3}$ atikahanindyarini@gmail.com
}

Received: $08^{\text {th }}$ February 2021/ Revised: $09^{\text {th }}$ May 2021/ Accepted: $11^{\text {th }}$ May 2021

How to Cite: Santoso, E. N., Wardani, N. E., \& Anindyarini, A. (2021). Local wisdom Ulur-ulur tlaga buret ceremony in Tulungagung. Humaniora, 12(3), 209-215. https://doi.org/10.21512/humaniora.v12i3.7024

\begin{abstract}
The aims of the research were to describe the Ulur-ulur traditional ceremony, the procession, and the values of local wisdom in it. The research applied a qualitative study using a snowball sampling method with passive participant observation techniques and interviews. The researchers conducted in-depth interviews with notetaking and one-on-one interview techniques, namely by asking questions to the informants one by one and then recording the answers from the informants. The data validated by the source triangulation method were then analyzed using the Miles and Huberman research method which included data reduction, data presentation, and conclusion drawing. The research result shows that (1) the Ulur-ulur ceremony is one of the rituals that manifests the residents' gratitude for the abundant water sources for the residents' rice fields. (2) Ulur-ulur traditional ceremony procession consists of the preparation stage, jodhang procession, jamasan of Dewi Sri and Jaka Sedana statues, prayers and kajat, sowing flowers, and closes with a typical art performance of Tulungagung regency. (3) The practice of Ulur-ulur traditional ceremony has local wisdom values: religious, social, educational, historical, and economic values.
\end{abstract}

Keywords: local wisdom, wisdom values, Javanese culture, Ulur-ulur

\section{INTRODUCTION}

Local wisdom, according to Subadio in Brata (2016), generally can be considered as an identity or a cultural personality of a nation. Ahimsa in Rais (2017) has said that local wisdom can be defined as a set of knowledge and practices that can be used to solve problems at hand in a good and proper way. Meanwhile, Sedyawati in Rais (2017) has said that local wisdom is defined as a set of knowledge in a community, both from previous generations and from experiences related to the environment and other communities, to overcome life challenges. Local wisdom is a legacy from ancestors that contains symbols that aim to convey messages about values, norms, and rules to create public awareness in order to show uniformity and ignore the diversity that exists (Machmud, 2013). According to Dahliani, Soemarno, and Setijanti (2015), local wisdom is a harmonious relationship between humans and the natural environment influenced by culture.

Java is an island that has many tribes and various cultures. The cultures and traditions on Java Island are diverse elements merged into one complete unity. The diverse cultures on the Java island also have local culture as one of the elements. Diverse local culture is a cultural heritage that must be preserved as a must-have cultural identity. Some examples of the local culture are folklore or fairy tales, oral folklore, traditional ceremonies, regional dances, folk songs, and so forth.

One of the Javanese cultures that have a lot of local wisdom values is a traditional ceremony. The traditional ceremony is one of the Javanese cultures that contains folklore, history, and local wisdom. In Tulungagung regency, there is a traditional ceremony where the history of practice comes from oral tradition or folklore. Dananjaya (1991) has said that folklore 
is a part of the culture of a collective, which is spread and passed down from generation to generation, among various kinds of collectives, traditionally in different versions, both in verbal form and examples that are accompanied by gestures or reminder assistant devices (mnemonic device). Folklore is a part of the culture, spread through speech or orally; thus, folklore is also known as an oral tradition. However, the scope of folklore is broader when compared to the oral tradition, which includes only a few aspects of culture.

Several researchers have conducted research related to local wisdom on traditional ceremonies and the Ulur-ulur ceremonies. Wicaksono (2018), in his research, has explained the history of Ulur-ulur and the procession of carrying out the Ulur-ulur ceremony. Tricahyono and Sariyatun (2021) have explained the history of Ulur-ulur, processions, and value education in the field of Social Sciences. Research by Fajarini (2014) and Setyawan (2016) have stated that local wisdom plays a role in character education for students and can be a method of language learning. Royyani (2008) has conducted research on the Seren Taun traditional ceremony in Kuningan, West Java. The result of the first discussion is the practice of the Seren Taun ceremony as a gratitude ceremony for the abundance of water sources on the $22^{\text {nd }}$ of Rayagung, and the result of the second discussion is the values contained in the Seren Taun ceremony. Apart from Seren Taun, a traditional ceremony is held as a symbol of gratitude for the residents for the abundance of water for irrigation called Ngikis traditional ceremony. The ceremony, held at a site called Karangkamulyan, has been researched by Hidayatuloh (2019). This research focuses on wisdom values which include religious, social, language, art, history, culture, economy, knowledge and education, ethics, aesthetics, and the values of silih asah, silih asih, silih asuh.

Other research that discusses the values of local wisdom is the research conducted by Saddhono et al. (2019), with a research focus on the Nyadran traditional ceremony in Sragen regency as local wisdom of the community in doing earth alms. Susuk Wangan traditional ceremony, researched by Wulan, Suyitno, and Rohmadi (2018), is also a traditional ceremony that contains local wisdom. The research results of Wulan, Suyitno, and Rohmadi (2018) have shown that the Susuk Wangan traditional ceremony has educational value. Yuliningsih, Saddhono, and Setiawan (2018), in their research on Nyadran traditional ceremony, have provided the result of one of the values of local wisdom, namely the religious value contained in the Nyadran traditional ceremony.

Ritus Tiwu Panganten traditional ceremony is a ceremony held at a wedding, researched by Haryadi (2013) in Cirebon regency, also has the value of local wisdom. In addition, there are also traditional ceremonies known as the misalin traditional ceremony, which contain the values of local wisdom due to its series of village clean-up events and also self-purification to welcome the coming of the month of Ramadan in the Cimaragas area, Ciamis regency, as described in a research conducted by Ratih (2019). Fatimah, Sulistyo, and Saddhono (2017) have suggested that the value of local wisdom can also be found in oral stories or folklore found in Sayu Wiwit.

Ulur-ulur traditional ceremony is a ceremony with oral traditions, history, and local wisdom values. The research is important to provide insight to readers in general about the Ulur-ulur traditional ceremony. It aims to describe the Ulur-ulur traditional ceremony, Ulur-ulur traditional ceremony procession, and the local wisdom values contained in Ulur-ulur traditional ceremony.

\section{METHODS}

The research applies a qualitative method. Data collection uses the snowball sampling method with passive participant observation techniques and interviews. Before conducting research using these methods and techniques, the researchers make a list of questions. The passive participant observation method is carried out by participating them in the activities at the ceremony venue, namely Buret Lake. The researchers ask questions to informants who participated in the Ulur-ulur ceremony in the lake (tlaga).

When conducting the interview with informants, the researchers conduct in-depth interviews with notetaking interview and one-on-one interview techniques, namely by asking questions to the informants one by one and then recording answers. The results of recording the answers obtained from the informants were then summarized and sorted according to the researcher's data needs. Sorted are then validated using the source triangulation method. This validation is carried out by adjusting the data that the researchers obtained from the process of passive participant observation and interviews with informants. The validated data are then analyzed using the Miles and Huberman method, which includes data reduction, data presentation, and conclusion drawing.

\section{RESULTS AND DISCUSSIONS}

Traditional ceremony for the Javanese community is one of the events and rituals that are considered important and sacred. The community in Tulungagung, especially in the Campurdarat district, performs traditional ceremonies that have been carried out from generation to generation as a cultural heritage of their ancestors that must be maintained and preserved. The traditional ceremony in Campurdarat is called Ulur-ulur. This ceremony consists of several stages, starting with the preparation of the ceremony, arak-arakan, jamasan arca ritual, prayers, and kajat, ended with a typical art performance of Tulungagung regency and shadow puppets.

As a tradition passed down from generation to generation, the Ulur-ulur ceremony has a history that 
belongs to the type of oral tradition or folklore. Ulurulur traditional ceremony is carried out by the people in Campurdarat originated from the story that the guardian of Telaga Buret named Eyang Jigang Jaya wanted to call Dewi Sri and Jaka Sedana. This is done because of the long drought that hit four villages in Campurdarat, namely Sawo, Gedangan, Ngentrong, and Gamping. The dry season causes the residents' rice fields to experience drought and is threatened with crop failure. The drought that hit the villagers also causes Tlaga Buret, a source of irrigation for the residents' rice fields, to dry up. Another impact of the drought that befell the villagers is an outbreak of disease or known as pagebluk. This incident causes the community to work together to carry out the Sradda ceremony, which is a pepetri ceremony using offerings containing ruwatan or cleansing from all kinds of disasters, and entertainment in the form of tayuban art performances.

According to the narrative of Musiran, a village elder, the history of the Ulur-ulur traditional ceremony is begun with an epidemic that afflicted the community called pagebluk meganturan. This situation causes the government retainer to feel worried and concerned. This makes the government retainer to meditate to gain instructions from God to overcome the epidemic that attacked the community. The clue that the government retainer has been received to overcome the plague and make the Campurdarat region even better is to hold a pepetri ceremony at Tlaga Buret.

The meaning of Ulur-ulur is nggawa ulu wektune bumi which means the time to give or distribute the people's harvest as a form of alms to the earth. Ulur-ulur is a procession to restore human consciousness to maintain the balance of nature with a ceremony as a medium of education for each generation on the importance of preserving nature for the future. Ulur-ulur ceremony aims to maintain the balance and preservation of nature so that Dewi Sri and Joko Sedana as symbols of fertility and prosperity will always be present in the midst of the life of the community in Tlaga Buret.

Ulur-ulur traditional ceremony is held annually by the community living in Campurdarat district, especially residents in four villages, namely Sawo, Gedangan, Ngentrong, and Gamping. Ulur-ulur is commemorated and held every Sela month (based on the Javanese calendar and calculation) on the day of Jemuah Legi at Tlaga Buret Campurdarat. In the calculation of the Javanese calendar, there are certain years where Ulur-ulur is not performed on Jemuah Legi in Sela; thus, the Ulur-ulur ceremony is held on the day of Jemuah Pon according to Javanese calculations.

There is a kind of wewaler or taboo in Tlaga Buret and also during the Ulur-ulur ceremony. These suggestions include wearing a headband of blangkon gadung melati, raising a pancal panggung horse, looking for or killing animals in the lake and its surroundings. The dishes or food used for ceremonial offerings should not be tasted and must be cooked by a woman who is luwas sari (not in her period).

The practice of Ulur-ulur begins with a feast ceremony called the nglampet ceremony or also known as the Hep-hep ceremony, which is held at the Sawo village hall. Nglampet comes from the Javanese language ngampet, which means stopping or damming a river flow to flow the water into the villagers' rice fields. Other preparations are making offerings and ubarampe that would be used in ceremonies at the house of the Sawo village head. On the day of Jemuah Legi, a core event is held, which the schedule of events has been compiled by Paguyuban Sendang Tirta Mulya. It starts with arak-arakan from SMA Negeri 1 Campurdarat heading to Tlaga Buret. The arak-arakan is divided into several groups dressed according to the task of the group.

The first group is the group that served as the opening line and at the same time as dupa (incense) and padupan carriers dressed in surjan, a batik cloth with the motif of sido luhur, blangkon, and keris. The first group of arak-arakan is shown in Figure 1. The second group is a group of flower carriers wearing kebaya, jarik cloth, and sanggul (hair bun). The third group is the group that is tasked with bringing jodhang from the four villages which participate in the Ulur-ulur ceremony in pranakan clothes. The fourth group is a closing group consisting of invited guests, pengrawit (karawitan), and Tulungagung's reog kendhang dancers.

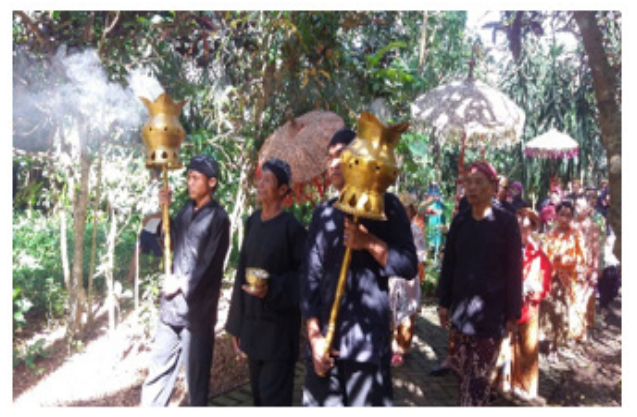

Figure 1 Arak-Arakan

The arak-arakan group that arrived at Tlaga Buret goes straight to the table that has been prepared to put the jodhang that has been paraded from SMA Negeri 1 Campurdarat. The jodhang contains food in the form of sekul suci ulam sari, sega gurih, buceng kuat, ambeng mule, buceng robyong, jenang ngapura, jenang sengkala, jadah waran, jadah putih, jadahabang, jadah kuning, jadah ireng, wajik, ketan, and ketan kinco.

The nine-colored cakes, or what is known as jajan manca warni maes agung, are traditional snacks and tubers in different colors that are brought by each villager. Other ubarampe needed are plantain, cok bakal, badheg tape, candu, kemenyan, minyak wangi, kembang telon (three-colored flowers), gantal, gula gimbal, gula glising, and coconut without coir. All 
ubarampe are put into bokor, except for kendi, klasa (mat), and topi janur (coconut hat).

Jenang sengkala denotes the sign of a ceremony (nyengkalani upacara) as a sign for the water source (kanggo nyengkalani sumber) to remain sustainable and not dry forever. Jenang ngapura means if someone has a mistake in performing Ulur-ulur nyuwun pangapunten ceremony or asking for forgiveness. Boreh as a complement to ubarampe is used as a powder for the statue of Dewi Sri and Jaka Sedana, lawe thread as a symbol for light, and coconut that has been peeled without coir as a symbol of oil used together with lawe thread for lighting or lamps.

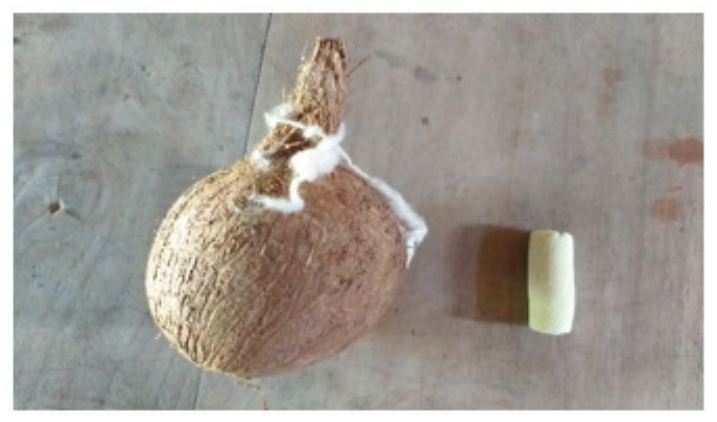

Figure 2 Coconut, Lawe, Boreh

The ceremony begins with bathing the bridal statue, which is a symbol of Dewi Sri and Jaka Sedana. The baths of Dewi Sri and Jaka Sedana statues are equipped with ubarampe, which consists of three types placed in different containers. Ubarampe for the jamasan statue procession includes rice, krambil, gedhang raja setangkep, cok bakal takir (lombok, bawang, brambang, miri, bumbon pawon, kacangkacangan), boreh panji anom, pandan wangi, a small mirror, lenga wangi sri gandhas wangi, suri, and kembang (flowers). The procession of bathing the statues of Dewi Sri and Jaka Sedana is accompanied by prayers and kajat led by traditional elders.

The offerings and ubarampe provided for the statues of Dewi Sri and Jaka Sedana are in the form of decorative equipment, which is interpreted as a symbol that after being bathed with water and seven forms of flowers, Dewi Sri and Jaka Sedana also need to be decorated. The decorative items used are boreh panji anom as a powder, suri or a comb as a symbol to comb the hair, lenga wangi sri gandhas wangi as a symbol for body fragrances, and a small mirror used as a symbol to reflect while being decorated. All offerings and ubarampe for the procession of the statues of Dewi Sri and Jaka Sedana are put into a container made of brass called bokor, which can be seen in Figure 3.

The prayers and kajat used in Ulur-ulur traditional ceremonies are a combination of Javanese and Islamic prayers. Prayer and kajat for community members and invited guests:

"Dhumateng para kadang paguh sedaya ingkang ndherek upacara slameta rahayu wilujeng lan nyengkuyung upacara adat ulurulur lan mula metri malih sumber ingkang wonten tlaga keparingipun Gusti ingkang Maha Agung sageda lestantun sampun ngantos sat, sageda mahanani among tani juru tani wonten sabendinanipun".

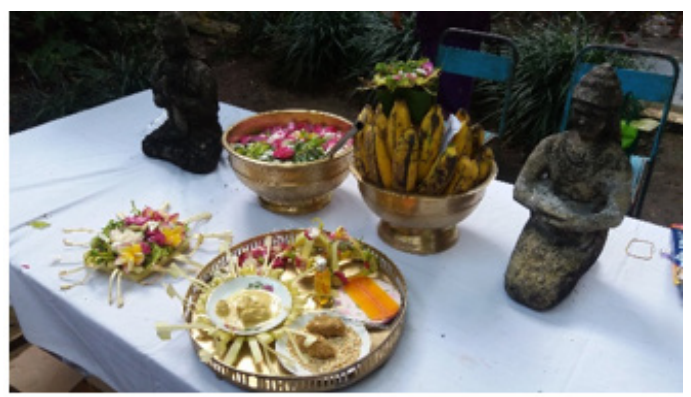

Figure 3 Statues of Dewi Sri and Jaka Sedana

The translation of the prayer is "to all of you who participate in the ceremony; hopefully, you are safe and prosperous and helpful for ulur-ulur traditional ceremonies and praying for the lake water source given by God."

Prayer and kajat for jajan manca warni maes agung:

"Agunga sumberipun sedayanipun sampun ngantos surut, mahanani rahayu nggih para kadang ingkang ndherek upacara sageda agung rejekine, agung kaslametane wiwit ngandhap ngantos nginggil dipunsuwun pangestune wilujeng".

The translation of prayer for jajan manca warni is to be a great source of everything, not to subside, to be a safety for participants who take part in the ceremony. Hopefully the participants can have a large fortune, great safety from beginning to end.

Prayer and kajat for ubarampe and cok bakal:

"Cok bakal, gula gimbal, gula glising: ngaturi eyang-eyang ingkang nengga toya panenger niki inggih sedayanipun ingkang sami nenempuh dayanipun kalangsungan sesaji cok bakal kaliyan gula gimbal gula glising, kirang ganda kirang rasa nyuwun pangapunten saageng-agengipun, sageda rahayu lan menapa kemawon ingkang tumindak ala contonipun nebangi kajeng wonten ngriki suksamen sukani pepenget mugi-mugi sampun ngantos ngoten, dipunsuwun pangestunipun".

The translation for ubarampe and cok bakal is addressed to the ancestors who are waiting for the water and all the forces that maintain the existence of the offerings of cok bakal, gula gimbal, gula glising, great apology for less fragrant and less taste. It hopefully can be safe, and anyone who commits crimes, such as 
cutting down the trees in this area, may his soul get a warning not to commit the aforementioned crimes. offerings:

Prayer and kajat for the chicken and rice

"Sekul suci ulam sari : kumanten dhumateng mbok Sri lan Jaka Sedana minangka sesembahaning among tani juru tani minangka dewane among tani juru tani, sageda sami teteguh ayem tentrem wonten mriki, lan rumiyin satus dinten wonten papan ara-ra amba pasabingan ara-ara amba ngantos samenika panturami pinanggih enggal, pramila mbok Sri lan Jaka Sedana sageda sesiram jamah, sageda tentrem ayem wonten dusun Sawo ngriki mahenani kacekapane among tani juru tani, saged ayem tentrem nuhoni urip saderma, Gusti mugi ngijaboni ingkang dados panuwun lan dipunsuwun".

The translation of the prayer is addressed to Dewi Sri and Jaka Sedana as the gods for the peasants. Hopefully there can be peace in this place, and previously for a hundred days in this vast, infinite place until now it has become a new place, so that Dewi Sri and Jaka Sedana can give happiness, can be peaceful in this Sawo village, can live well, may God grant what the community requested. ceremony:

Prayer and kajat for the closing of the ulur-ulur

"Kabuncang ing maruta. Tandesna mring jalanedi. Hasta seni pamadyaning langgeng. Jagad kang paring kuwat. Bumi kang paring rejeki. Surya, candra, kartika, kang pinangka saksi. Tinebihna tulak sarik, tingkakna sak kersane. Piantun desa, Sawo, Ngentrong, Gedangan, Gamping. Sumawana sak kabupaten Tulungagung. Minggah sak Negari Nusantara, Pinaringan Hayam, Hayem, Tentrem, Rahayu, Rahayu, Rahayu. Saking kersaning kang murbeng jagat".

The translation of the closing prayer for Ulurulur ceremony is carried by the wind, the hand asking for sustainability. Nature that gives strength. Earth that provides fortune. The sun, moon, stars are witnesses. Keep away from all infamy, residents of the villages of Sawo, Ngentrong, Gamping, Gedangan and all residents of Tulungagung regency, all residents of the same archipelago, may be given serenity, peace and safety from God who controls the nature. Figure 4 shows Jodhang Sesaji and Ubarampe.

After the jamasan of Dewi Sri and Jaka Sedana statues are finished, the offerings that have been prayed for are then taken in small amounts and then placed in a takir to be thrown into Tlaga Buret along with the ritual of sowing flowers. The rituals of larung sesaji and tabor bunga are a form of gratitude of the residents from the villages of Sawo, Ngentrong, Gedangan, and Gamping for the abundance of their crops whose irrigation source comes from Tlaga Buret. It can be seen in Figure 5.

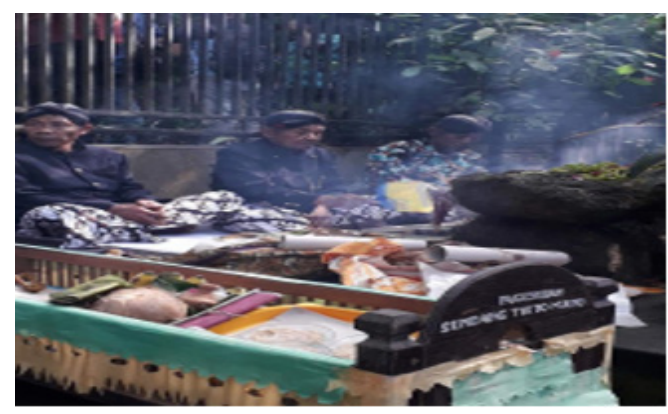

Figure 4 Jodhang Sesaji and Ubarampe

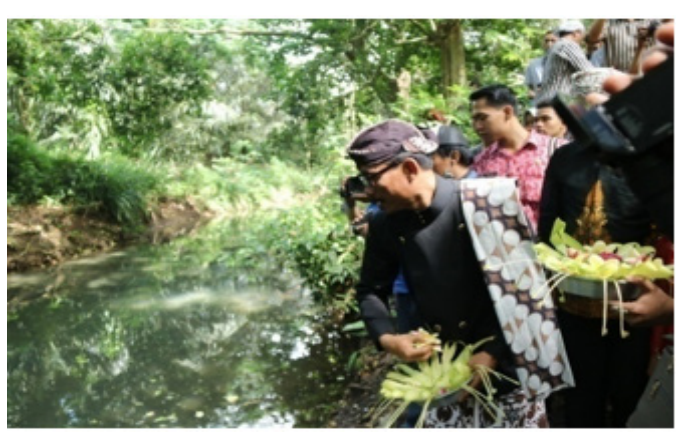

Figure 5 Sowing Flowers and Sesaji

The value of local wisdom provides many lessons. The value of local wisdom can not only be obtained from the family circle but also from customary activities that are passed down from generation to generation. This traditional ceremony activity contains a lot of local wisdom values. One of the traditional activities which contain cultural values is Ulur-ulur traditional ceremony. Supratno (2010) has explained that cultural value functions as a guide for life and good guidance for a particular society. The cultural values contained in Ulur-ulur traditional ceremony are religious, social, educational, historical, and economic values.

The practice of Ulur-ulur traditional ceremony at Tlaga Buret is always related to religious elements or community beliefs. Religious values are related to humans and God. The objective of carrying out the Ulur-ulur traditional ceremony is as a form of gratitude to God for the success of the harvest and the fulfillment of daily needs. The prayers and kajat offered during the ceremonial procession are prayers in Javanese and Islamic languages. The religious value contained in Ulur-ulur traditional ceremony can always be a reminder and as a gratitude for the blessings given by God. Through the Ulur-Ulur ceremony, the community in Sawo village will always have faith in God and stay away from bad things that can have a negative impact on life.

Second is the social value of the Ulur-ulur traditional ceremony. Social values are contained in 
the relationship between one individual and another or between a group of community and another. This relationship is the establishment of harmony and gotong royong (mutual cooperation) among the residents of the four villages of Sawo, Gedangan, Ngentrong, and Gamping. Gotong royong between villagers is able to create harmony between the villagers. Villagers can help each other to carry out Ulur-ulur traditional ceremonies; thus, they have a sense of responsibility. The values of harmony and gotong royong contained in the Ulur-ulur traditional ceremony make the residents of four villages a solid and stable community group. The solidarity of the villagers of Sawo, Ngenrong, Gedangan, and Gamping in carrying out the Ulur-ulur traditional ceremony makes this ceremony can be maintained and passed on from generation to generation.

Thirdly, the knowledge value of the Ulur-ulur traditional ceremony is that it can educate community members to always maintain cultural heritage and preserve the natural environment. Tlaga Buret, as the place for the practice of Ulur-ulur ceremony, has been designated by the Tulungagung regency government as a protected forest area in the Tulungagung Regency Regional Regulation Number 11 the Year 2012 concerning Regional Spatial Planning. Apart from being a source of irrigation for the residents' rice fields, Tlaga Buret is also a habitat for some fauna, such as deers, softshell turtles, black monkeys, and several species of birds. This becomes the value of education needed by the community members to protect the cultural heritage and natural environment.

The fourth is the historical value of the Ulurulur traditional ceremony. The implementation of traditional ceremonies cannot be separated from history. Ulur-ulur has a history that comes from Eyang Jigang Jaya, who became the guardian of the Tlaga Buret area in order to maintain its sustainability, aiming to call Dewi Sri and Jaka Sedana as fertility gods. The long dry season and pagebluk meganturan that brought an epidemic of deadly diseases to the community becomes the historical background for the practice of Ulur-ulur traditional ceremony. This is what makes Ulur-ulur traditional ceremony historic for the residents of the villages of Sawo, Ngentrong, Gedangan, and Gamping. Throughout this history, the villagers maintain to practice the Ulur-ulur ceremony as a form of respect for their ancestors.

The next local wisdom value is economic value. The economic value contained in this traditional ceremony can be felt by residents of the community around Tlaga Buret who sell food around the lake. Ulur-ulur ceremony, an annual routine agenda, is a cultural event with its own uniqueness. Ulur-ulur traditional ceremony at Tlaga Buret is expected to bring in both domestic and foreign tourists because of the traditional ceremonial activities closely related to culture and tourism.

\section{CONCLUSIONS}

Culture from various regions has its own uniqueness and characteristics. One of the cultures that are still maintained and held is Ulur-ulur traditional ceremony. This ceremony is one of the rituals and an annual routine agenda for the residents of Sawo, Ngentrong, Gedangan, and Gamping villages. It has objectives to manifest residents' gratitude for the abundant water sources for their rice fields and the preservation of the lake environment. Ulurulur traditional ceremony procession consists of the preparation stage, arak-arakan jodhang, jamasan of Dewi Sri and Jaka Sedana statues, prayers and kajat, tabur bunga (sowing flowers), and is closed with a typical art performance of Tulungagung regency. The practice of Ulur-ulur traditional ceremony has local wisdom values, namely religious, social, and knowledge values. The local wisdom values contained in Ulur-ulur traditional ceremonies need to be maintained and preserved.

The research contributes to the field of culture. The analysis provides an overview of the values of local wisdom in the Ulur-ulur traditional ceremony. The limitations of the research are expected to be an evaluation for further research related to local wisdom values in traditional ceremonies in Tulungagung regency, especially those related to Ulur-ulur.

\section{REFERENCES}

Brata, I. B. (2016). Kearifan budaya lokal perekat identitas bangsa. Jurnal Bakti Saraswati, 5(1), 9-16.

Dahliani., Soemarno, I., \& Setijanti, P. (2015). Local wisdom in built environment in globalization era. International Journal of Education and Research, 3(6), 157-166.

Dananjaya, J. (1991). Folklor Indonesia ilmu gosip, dongeng, dan lain-lain ( $3^{\text {rd }}$ Ed.). Jakarta: PT Temprint.

Fajarini, U. (2014). Peranan kearifan lokal dalam pendidikan karakter. Sosio Didaktika: Social Science Education Journal, 2(1), 123-130. https://doi.org/10.15408/ sd.v1i2.1225.

Fatimah, F. N., Sulistyo, E. T., \& Saddhono, K. (2017). Local wisdom values in Sayu Wiwit folklore as the revilization of behaviorisme education. Karsa: Journal of Social and Islamic Culture, 25(1), 179199. https://doi.org/10.19105/karsa.v25i1.1266.

Haryadi, F. (2013). Nilai kearifan lokal dalam upacara adat Ritus Tiwu Panganten di kecamatan Babakan kabupaten Cirebon (Analisis struktural-semiotik). Lokabasa: Jurnal Kajian Bahasa, Sastra dan Budaya Daerah serta Pengajarannya, 4(2), 112121. https://doi.org/10.17509/jlb.v4i2.3133

Hidayatuloh, S. (2019). Nilai-nilai kearifan lokal upacara adat Ngikis di situs Karangkamulyan kabupaten Ciamis. Patanjala, 11(1), 97-113. https://doi. org/10.30959/patanjala.v11i1.445.

Machmud, M. (2013). Heritage media and local wisdom of 
Indonesian society. Global Journal of Human Social Science, Arts, and Humanities, 13(6), 57-66.

Rais, W. A. (2017). Kearifan lokal dalam bahasa dan budaya Jawa: Studi kasus masyarakat nelayan di Pesisir Selatan Kebumen Jawa Tengah (Kajian etnolinguistik) ( $1^{\text {st }}$ Ed.). Surakarta: UNS Press.

Ratih, D. (2019). Nilai-nilai kearifan local dalam tradisi Misalin di kecamatan Cimaragas kabupaten Ciamis. Istoria: Jurnal Pendidikan dan Sejarah, 15(1), 4557. https://doi.org/10.21831/istoria.v15i1.24184.

Royyani, M. F. (2008). Upacara Seren Taun di Cigugur, kabupaten Kuningan, Jawa Barat: Tradisi sebagai basis pelestarian lingkungan. Jurnal Biologi Indonesia, 4(5), 399-415. http://dx.doi. org/10.14203/jbi.v4i5.3222.

Saddhono, K., Setiawan, B., Yuliningsih, Y., \& Rahmaniar, F. (2019). Local wisdom on Nyadran tradition in Sragen regency. Proceedings of the $2^{\text {nd }}$ International Conference on Local Wisdom, INCOLWIS 2019. Padang, Indonesia. pp 1-6. http://dx.doi.org/10.4108/ eai.29-8-2019.2288957.

Setyawan, B. W. (2016). Learning method based on local wisdom for language learning Javanese. Proceeding International Conference on Education and Training. Malang, Indonesia.
Supratno, H. (2010). Aktulaisasi nilai-nilai tradisi lisan berwawasan kepulauan sebagai model pendidikan karakter bangsa. Ambon: Himbasadi.

Tricahyono, D., \& Sariyatun, S. (2021). Tradisi ulurulur ditinjau dari pendekatan konstruktivisme sebagai upaya penguatan pendidikan nilai dalam pembelajaran IPS. Aksara, 7(1), 79-88. http://dx.doi. org/10.37905/aksara.7.1.79-88.2021.

Wicaksono, P. I. (2018). Studi pelaksanaan upacara UlurUlur desa Sawo kecamatan Campurdarat kabupaten Tulungagung tahun 2018. Jurnal Simki Pedagogia, 3(4), 1-14.

Wulan, D. R. R., Suyitno, S., \& Rohmadi, M. (2018). The education values of Susuk Wangan tradition as the forming of character in the milenial era. El-Harakah: Jurnal Budaya Islam, 20(2), 215-231. https:/doi. org/10.18860/el.v20i2.4931.

Yuliningsih, Y., Saddhono, K., \& Setiawan, B. (2018). Religious value in Nyadran ceremony in Ngepringan village, Sragen. El-Harakah: Jurnal Budaya Islam, 20(2), 155-173. https://doi.org/10.18860/ el.v20i2.4981. 